\title{
Flood Inundation Evolution of Barrier Lake and Evaluation of Regional Ecological Spatiotemporal Response - A Case Study of Sichuan-Tibet Region
}

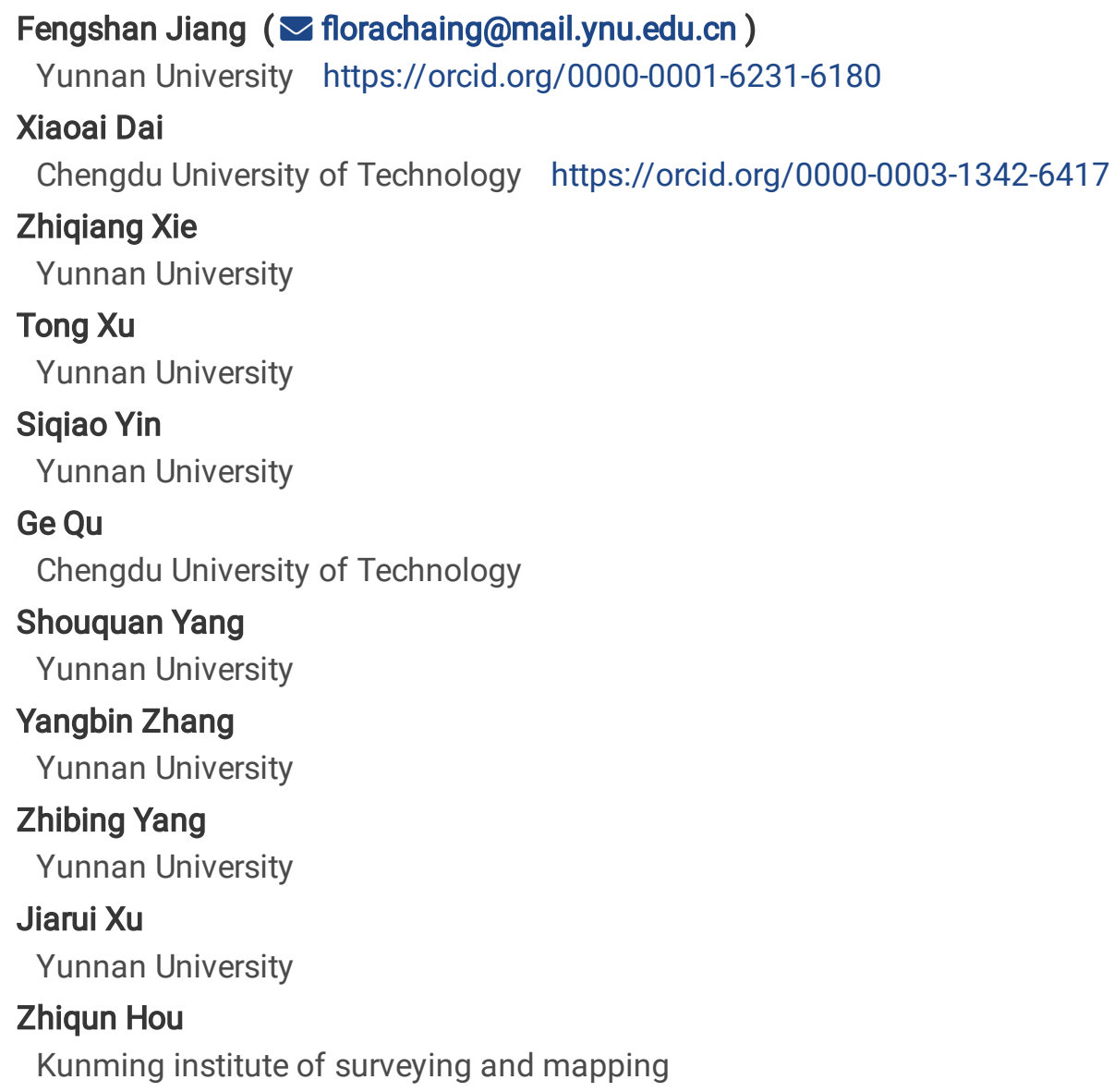

\section{Research Article}

Keywords: dammed lake, regional ecology, flood simulation, habitat quality

Posted Date: December 7th, 2021

DOI: https://doi.org/10.21203/rs.3.rs-1033166/v1

License: (c) (i) This work is licensed under a Creative Commons Attribution 4.0 International License. Read Full License 


\section{Abstract}

The Sichuan-Tibet region of China has always been an area with frequent earthquake disasters, accompanied by the occurrence and collapse of dammed lakes. The collapse of dammed lakes seriously threatens the lives and property safety of downstream personnel. At the same time, domestic and foreign scholars are concerned about the surrounding dammed lake there are few ecological studies on the lake, and the impact of the dammed lake on the ecology has very important enlightenment significance for our lake construction project. It is the purpose of this article to scientifically predict the risk of dam break in a barrier lake, explore its impact on the ecological environment and put forward control measures. Based on the four major dammed lake events of Diexihaizi, Tangjiashan dammed lake, and Hongshihe dammed lake in the Sichuan-Tibet area, this paper extracts water bodies from remote sensing images and uses the HEC-RAS model to determine whether there is a risk of the dam break and whether Forecast the route of the dam; and use the InVEST model to evaluate and analyze the habitat of the smallest administrative district (county/district) where it is located from 1990 to 2020 and make an evaluation based on the results of flood inundation. The results show that the stable dammed lake (Diexi Haizi) after engineering treatment has a stabilizing effect on the habitat quality index. The formation of the dammed lake has changed the nearby land-use types and the regional landscape ecological pattern. The habitat quality index will decrease slightly in the $1 \mathrm{~km}$ area around Sai Lake, but the habitat quality will increase in the $3 \mathrm{~km}$ area and the $5 \mathrm{~km}$ area. Artificial flood discharge and engineering reinforcement of barrier lakes are necessary. In this paper, the areas with strong human control will recover better than other regions' habitat quality index.

\section{Introduction}

As early as 1786, there was a record of barrier lakes. The landslide in Moxi-mian dammed the lake induced by an earthquake, and floods inundated the lower reaches, causing the death of more than 100,000 downstream residents(Dai et al. 2004). In 1933, the Diexi barrier lake formed by the Diexi earthquake landslide in the Minjiang River Basin was also studied by many scholars as a model: through the application of fuzzy comprehensive evaluation to the evaluation of the risk of landslide blocking the river, 10 participating factors were established, and the Diexi The barrier lake is analyzed(Chai et al. 1997). Some scholars systematically introduced the basic characteristics of diexi ancient barrier lake and preliminarily discussed the geological environment information contained in diexi ancient barrier lake by investigating the existing landslide(Wang et al. 2005).

Before 2008, we knew for the lake are mostly written, or visiting the lake relics (just like diexi lake). Since the "5.12" Wenchuan earthquake, the emergence of 34 quake lakes, many scholars in view of the different types of lake dam research and the study of the flood, of which there is a lot of the tangjiashan quake lake as the study area. The risk of dam-break of tangjiashan barrier lake and its influence were summarized by the authors. On this basis, the key areas and suggestions for future research on the dam-break lake were put forward (Kuang et al. 2008).

At the same time, these barrier lakes have experienced a series of governance and human intervention after the outburst, now the more stable barrier lakes. For the Wenchuan earthquake formed another major quake lake, there are also many scholars for the research area. The JetIndex method is used to measure the erosion of soil proposed by Hanson, and the dam break risk of Hongshi river barrier lake is evaluated (Chang et al. 2009). There are also scholars using multi-source remote sensing data to study, and on this basis, to further determine the type of barrier lake, characteristics, and harm to provide a basis (Fan et al. 2008). Earthquakes form most of the barrier lakes, so it is necessary to sum up the rules of their formation and put forward solutions. In recent years, based on the geomorphic dimensionless accumulation index method, some scholars have discriminated the risk of dam-break of laterite dam, estimated the flood of dam-break of barrier lake, and estimated the flood of the downstream evolution process (Liu et al. 2016). By analyzing the risk assessment flow chart of the barrier lake, the collaborative work process and dynamic group control mechanism were designed to improve the efficiency of emergency response to the risk of dam failure of the barrier lake (Song et al. 2011). The theory of distributed virtual reality and GIS is used to construct DVGE with technology, which supports the risk assessment and impact analysis of the dam failure of the 
barrier lake(Zhu et al. 2012). Some scholars also used quick and detailed procedures to assess the risk of inundation, and used the case of a landslide dam in southern Taiwan to prove the usability of the systematic method(Yang et al. 2013) .

In the past five years, quake lakes triggered by earthquakes and heavy rains are numerous. In October 2018, the Jinsha River cut off the flow led to the formation of a barrier lake, after two landslides, a large area of road collapse, the road was completely interrupted, and rescued difficulties, until November 14,2018 , only to successfully discharge, the inconvenience caused during the economic losses cannot be calculated (Zhan et al.2017;Xu et al.2018; Chen et al.2020).

Flow-3d software, MIKE11 model and HEC-RAS model were used to calculate the burst Flow and realize the flood inundation evolution(Hafiyyan Q et al. 2021), and visualization of the process is the main means of study on the dam-break of the barrier lake(Liang et al.2021; Li et al.2021;Ma et al.2021). There are also more and more scholars using different fields of technology to study barrier lake. Taking some more accurate data, more advanced means, more efficient data processing methods, such as the improved UAV tilt photography and LiDAR method were used to obtain the multi-resolution time series data of the weir body. Through optical remote sensing images and interferometric synthetic aperture radar, using the depth-divided continuum method, the dynamic process of landslides is analyzed (Ouyang et al. 2019). Coupling the publicity proposed by railway scientific research and Xie Renzhi's progressive dam break model, an improved dammed lake progressive dam break model is proposed and its practicability is verified (Guo et al. 2020). Realizing the rapid acquisition and processing of high-precision terrain and image data. It provides numerical simulation support for the emergency rescue of the barrier lake(Sun et al.2021).

Barrier lake emergency rescue is very important, its' surrounding ecology is equally important. Many scholars study regional ecology. As early as 1985, some scholars evaluated the ecological environment of the whole Minjiang River basin(Wang 1985). Then, according to different characteristics and research scales, the evaluation methods are divided into indicator species evaluation method and index system evaluation method(Chen et al.2002). Based on the analysis of land use change, the paper puts forward that optimizing land use pattern in watershed can ensure ecological security(Yu et al.2006). Some scholars also applied InVEST model in the field to verify the Miyun reservoir watershed(Li et al.2013). Through the study of the treatment project, the ecological footprint calculation model is adopted, which provides the basis for the treatment project of Hongshiyan barrier lake(Hu et al,2017). For scholars to study the evolution of flood the lake has a lot of, for lake basin habitat quality also has a lot of research scholars, but the combination of scholars is relatively less, some scholars use relatively simple map superposition method and factor weight sum method for 2015 the Tangjiashan barrier lake reservoir area is analyzed(Yang et al.2014; Yang et al.2017). However, it also has obvious shortcomings. First, it only uses data from 2015 , and second, the method is not precise enough.

In view of the lack of current research, based on the four major quake lake events in the Sichuan-Tibet region of China, according to the parameter data of the quake lake in the existing papers, the HEC-RAS model was used to analyze the flood of the quake lake and judge the possibility of the bursting of the quake lake(Tian et al.2012). If there is no barrier lake, the bursting situation of the barrier lake is simulated(Peng et al.2012). Based on the ecological quality model, the long-term ecological impact of the lake basin was analyzed. Taking the typical barrier lake in southwest China as the research content, according to the difference of each region. The evaluation criteria of the ecological model in different regions are established, and the submerged area of the barrier lake and its influence on the surrounding ecology are finally analyzed. The ecological changes in the region are monitored in a long time series(Zheng et al.2018).

\section{Materials And Methods}

\section{Study area and sample collection}

Sichuan-Tibet region is located in southwest China, one of the seven subregions of China. The terrain in this region is undulating, complicated, and the natural environment is extremely harsh(Ji et al.2019;Xu et al.2021). Earthquake and landslide disasters occur frequently, the formation of quake lake after the occurrence of a landslide blocking the river, the formation of quake lake burst, will greatly threaten the safety of people's lives and property, the destruction of regional habitat 
is inestimable. The surface undulations in the region vary greatly, spanning first-level ladder and second-level ladder, among which: lowland basins, plains, small undulating low mountains, and small undulating middle mountains have a larger area(Gan et al.2017;Wang et al.2020).

Corresponding to the topographical area, the Sichuan Basin presents a humid mid-subtropical monsoon climate. Due to the uplift of the Qinghai-Tibet Plateau, the temperature and precipitation in this area vary greatly from northwest to southeast. The average annual temperature in the east reaches $24^{\circ} \mathrm{C}$, and the average annual temperature in the west is the lowest. Below $0^{\circ} \mathrm{C}$, there are obvious dry and rainy seasons(Li et al.2020;Xiang et al.2020).

The main data is shown in the table below:

Table 1

Data source table

\begin{tabular}{|c|c|c|}
\hline $\begin{array}{l}\text { Input } \\
\text { Data }\end{array}$ & Period & Description \\
\hline $\begin{array}{l}\text { Land } \\
\text { use/land } \\
\text { cover }\end{array}$ & $\begin{array}{l}19901995 \\
20002005 \\
20102015 \\
20182020\end{array}$ & $\begin{array}{l}\text { Chinese remote sensing image interpretation data (1990-2018) produced by the Resource } \\
\text { and Environmental Science Data Center of the Chinese Academy of Sciences and land use } \\
\text { data produced by the Ministry of Resources of China (2020). }\end{array}$ \\
\hline \multirow{2}{*}{$\begin{array}{l}\text { Barrier } \\
\text { lake } \\
\text { parameter } \\
\text { data }\end{array}$} & 19332008 & \multirow{2}{*}{$\begin{array}{l}\text { Integrate the data from the yearbooks and local chronicles of each administrative region and } \\
\text { related documents to obtain relevant tables. }\end{array}$} \\
\hline & 2018 & \\
\hline $\begin{array}{l}\text { Threat } \\
\text { data }\end{array}$ & & $\begin{array}{l}\text { A CSV table of all threats that need to be considered in the model. The table contains } \\
\text { information about the relative importance or weight of each threat and its impact across } \\
\text { space. Each row is a source of degradation. Each column contains different attributes of } \\
\text { each degradation source(Table 2). }\end{array}$ \\
\hline $\begin{array}{l}\text { Threat } \\
\text { raster }\end{array}$ & & $\begin{array}{l}\text { The GIS raster file contains the distribution and intensity of each threat, showing that each } \\
\text { threat affects the habitat. However, the technology applied to each threat grid differs } \\
\text { depending on the type of data, and it mainly evaluates and classifies the suitability of the } \\
\text { habitat. }\end{array}$ \\
\hline $\begin{array}{l}\text { Habitat } \\
\text { types and } \\
\text { sensitivity }\end{array}$ & & $\begin{array}{l}\text { The LULC type CSV table contains information on the specific susceptibility to each threat. } \\
\text { The sensitivity value ranges from } 0 \text { to } 1 \text {, where } 0 \text { means not sensitive to threats and } 1 \text { means } \\
\text { maximum sensitivity. }\end{array}$ \\
\hline \multicolumn{3}{|l|}{$\begin{array}{l}\text { of each } \\
\text { habitat to } \\
\text { threats }\end{array}$} \\
\hline $\begin{array}{l}\text { Digital } \\
\text { Elevation } \\
\text { Model } \\
\text { data }\end{array}$ & 2017 & $\begin{array}{l}\text { The data download comes from the Geospatial Data Cloud (China) with a resolution of } 30 \\
\mathrm{~m} \times 30 \mathrm{~m} \text {. }\end{array}$ \\
\hline \multirow{3}{*}{$\begin{array}{l}\text { Extract } \\
\text { data from } \\
\text { water } \\
\text { surface }\end{array}$} & 19902000 & \multirow{3}{*}{$\begin{array}{l}\text { Compare the methods of extracting water bodies, choose to extract water bodies in } \\
\text { mountainous areas, and choose the revised normalized difference water index. }\end{array}$} \\
\hline & 20102015 & \\
\hline & 2018 & \\
\hline
\end{tabular}

\section{Barrier lakes in the study area}

This article mainly studies the flood inundation evolution of barrier lakes in the Sichuan-Tibet area and the impact of barrier lakes on the ecology of the basin.

\section{Diexi Haizi}


In 1933, a magnitude 7.5 earthquake occurred in Diexi, which formed Diexi Haizi. It is located in Maoxian County, Aba Tibetan, and Qiang Autonomous Prefecture, the largest settlement of Qiang in China. It has a long history, but it is of great research value. (Fan et al.2019; Xu et al.2019; Wang et al.2020; Xu et al.2020; Wei et al.2021).

\section{Tangjiashan Barrier Lake}

On May 12, 2008, a magnitude 8.0 earthquake occurred in Wenchuan County, Sichuan Province, China. A huge landslide occurred in Tangjiashan on the right bank of Tongkou River in Sichuan and 6 kilometers away from Beichuan County. The landslide cut and blocked the river. Formed the most severe dammed lake in the earthquake. At present, this dammed lake has become a bay of still water. (Zheng et al.2015; Kidyaeva et al.2017; Li et al.2020; Zhu et al.2021).

\section{Hongshi river barrier lake}

The Hongshi River barrier lake in Qingchuan County, Sichuan Province is one of 34 large barrier lakes formed by the Wenchuan earthquake. It was formed by the Donghekou landslide blocking the Hongshi River. The Hongshi river barrier lake is in a group of barrier lakes. The upper reaches are the Shibangou barrier lake and the Donghekou barrier lake, and the lower reaches are the Libaisi barrier lake(Li et al.2008; Chang et al.2009; Shi et al.2015).

\section{Baige Barrier Lake of Jinsha River}

On October 11 and November 3, 2018, two large-scale high-level landslides occurred on the right bank of the Jinsha River at the junction of Baige Village, Boluo Township, Jiangda County, Tibet Autonomous Region, and Zeba Village, Ronggai Township, Baiyu County, Sichuan Province. The Jinsha River formed a barrier lake. After the manual intervention, the dammed body began to discharge on November 12, and until the 13th, the water level of the upper and lower reaches of the dam body was through, and the danger of the barrier lake was lifted(Zeng et al.2019; Zhou et al.2019; Chen et al.2020; Zhang et al.2020).

\section{Method}

Determine the stability of the barrier lake after analyzing the impact of the dam break of the barrier lake, and analyze the habitat quality of the barrier lake area. The specific process is shown in the following figure.

\section{Flood dam break simulation method}

HEC-RAS is mainly composed of four parts: unsteady flow simulation, water quality analysis, constant flow water surface line calculation, and movable boundary sediment transport calculation. Among them, the two-dimensional hydrodynamic model, with high accuracy and simple construction requirements, is more suitable for various scenarios such as flooding in plain areas and is used by many people. This research mainly uses the dam break calculation module and the flood evolution module among them (Chen et al.2006; Xu et al.2011; He et al.2015; Habtamu et al.2021).

The HEC-RAS two-dimensional hydrodynamic model uses the shallow water equation, which is a two-dimensional simplified form of the Navier-Stokes equation.

Continuous equation

$$
\frac{\partial H}{\partial \mathrm{t}}+\nabla \cdot h \mathrm{w}+q=0
$$

Momentum equation

$$
\frac{\partial \ddot{V}}{\partial t}+T \& \nabla I \&=-g \nabla H+v_{t} \nabla^{2} T^{\&}-c_{f} I^{\&}+f k \times \&
$$

In the formula, $\mathrm{H}$ is the water surface elevation, $\mathrm{m}$; $\mathrm{h}$ is the water depth, $\mathrm{m}$; is the flow velocity, $\mathrm{m} / \mathrm{s}$; $\mathrm{R}$ is the hydraulic radius, $\mathrm{m} ; \mathrm{q}$ is the side inflow single-width flow, $\mathrm{m}^{2} / \mathrm{s} ; \mathrm{g}$ is the acceleration of gravity, $\mathrm{m} / \mathrm{s}^{2}$; ut is the kinematic viscosity in the 
horizontal direction, $\mathrm{m} 2 / \mathrm{s}$; cf is the roughness of the bottom of the river bed; $f$ is the Coriolis coefficient; $k$ is the unit vector in the vertical direction; $\mathrm{n}$ is the roughness.

The outflow from the breach is calculated on the assumption of a wide crested weir, and the calculation equation is

$$
Q=\sigma_{s} \varepsilon m B^{\prime} \sqrt{2 g}\left(Z_{i}-Z_{i+1}\right)^{\frac{3}{2}}
$$

In the formula, $\mathrm{Q}$ is the flow rate, $\mathrm{m}^{3} / \mathrm{s} ; \mathbb{Q}$ is the weir side collection coefficient; $\mathrm{m}$ is the flow coefficient; $B$ is the width of the wide-crested weir, $m$; $s$ is the submergence coefficient; $Z_{i}, Z_{i+1}$ are the water levels before and after the weir, $M$.

At present, there are more and more factors involved in water conservancy projects, and the amount of information that needs to be processed is also increasing. The HEC center has developed the GeoRAS module, which is combined with GIS software to effectively simplify the preliminary data preparation work and facilitate the establishment of river topographic geometric data.

\section{Habitat Quality Model}

Land use/land cover change (LUCC) is an important content of global climate change and global environmental change research.

The habitat quality assessment method uses the InVEST model developed by the US Natural Capital Project Group. InVEST1.0 only includes two sub-modules: pollutant control, sediment and unclassified biodiversity, carbon storage, wood yield and crop pollination modules. Subsequent versions continue to refine the types of ecosystem service functions. As of April 2021, the InVEST model has been updated to version 3.9.0(Yu et al.2012; Pan et al.2016). In this version, ecosystem service functions include three major modules: supporting ecosystem services, In addition to the final ecological service and urban ecosystem, there are two analysis modules: module operation aids and support tools(Yang et al.2012; Wu et al.2013).

Table 2

Stress factor weight and maximum influence distance

\begin{tabular}{|llll|}
\hline Stress factor & Influence distance $/ \mathbf{k m}$ & Weights & Decay function \\
\hline Paddy field & 1 & 0.5 & Linear \\
\hline Dry land & 1 & 0.5 & Linear \\
\hline Urban land & 8 & 1 & Exponential \\
\hline Rural settlement & 5 & 0.7 & Exponential \\
\hline Other construction land & 2 & 0.5 & Linear \\
\hline
\end{tabular}


Table 3

Habitat suitability and sensitivity of stress factors

\begin{tabular}{|c|c|c|c|c|c|c|}
\hline \multirow[t]{2}{*}{ Land-use type } & \multirow{2}{*}{$\begin{array}{l}\text { Habitat } \\
\text { suitability }\end{array}$} & \multicolumn{5}{|c|}{ Sensitivity to stress factors } \\
\hline & & $\begin{array}{l}\text { Paddy } \\
\text { field }\end{array}$ & $\begin{array}{l}\text { Dry } \\
\text { land }\end{array}$ & $\begin{array}{l}\text { Urban } \\
\text { land }\end{array}$ & $\begin{array}{l}\text { Rural } \\
\text { settlement }\end{array}$ & $\begin{array}{l}\text { Other construction } \\
\text { land }\end{array}$ \\
\hline Paddy field & 0.4 & 0 & 1 & 0.7 & 0.5 & 0.4 \\
\hline Dry land & 0.4 & 1 & 0 & 0.7 & 0.5 & 0.5 \\
\hline Have woodland & 1 & 0.5 & 0.6 & 0.9 & 0.7 & 0.4 \\
\hline Bush forest & 0.8 & 0.4 & 0.5 & 0.7 & 0.6 & 0.5 \\
\hline Sparse woodland & 0.7 & 0.5 & 0.6 & 0.8 & 0.6 & 0.4 \\
\hline Other woodland & 0.4 & 0.5 & 0.6 & 0.8 & 0.6 & 0.4 \\
\hline High coverage grassland & 0.8 & 0.4 & 0.45 & 0.6 & 0.45 & 0.7 \\
\hline $\begin{array}{l}\text { Medium coverage } \\
\text { grassland }\end{array}$ & 0.6 & 0.45 & 0.5 & 0.65 & 0.5 & 0.7 \\
\hline Low coverage grassland & 0.4 & 0.5 & 0.55 & 0.7 & 0.55 & 0.7 \\
\hline River & 0.8 & 0.6 & 0.6 & 0.8 & 0.7 & 0.5 \\
\hline Lake & 0.9 & 0.55 & 0.6 & 0.9 & 0.7 & 0.4 \\
\hline Reservoir pond & 1 & 0.55 & 0.6 & 0.9 & 0.7 & 0.5 \\
\hline Glacier & 1 & 0.65 & 0.9 & 0.7 & 0.6 & 0.45 \\
\hline Tidal flat & 0.7 & 0.4 & 0.5 & 0.6 & 0.6 & 0.6 \\
\hline Urban land & 0 & 0 & 0 & 0 & 0 & 0 \\
\hline Rural settlement & 0 & 0 & 0 & 0 & 0 & 0 \\
\hline Other construction land & 0.3 & 0.3 & 0.5 & 0.4 & 0.5 & 0 \\
\hline Bare land & 0 & 0 & 0 & 0 & 0 & 0 \\
\hline Bare rock texture & 0 & 0 & 0 & 0 & 0 & 0 \\
\hline
\end{tabular}

\section{Flood Inundation Analysis}

\section{Diexi Haizi}

After the Diexi Earthquake, a total of 11 barrier lakes of varying specifications appeared. Over time, most of the barrier lakes have been broken. At present, only two barrier lakes, one large and one small, remain. The occurrence of the Diexi Earthquake is quite a long time ago. However, we can also see the evolution trend of the barrier lake from the changes in the water area of the barrier lake in recent years. 
Table 4

Statistical investigation table of the characteristics of the barrier lake in Diexi (part of 1995)

\begin{tabular}{|c|c|c|c|c|c|c|c|}
\hline Name & Location & $\begin{array}{l}\text { Average } \\
\text { length(m) }\end{array}$ & $\begin{array}{l}\text { Average } \\
\text { width } \\
\text { (m) }\end{array}$ & Depth(m) & $\begin{array}{l}\text { Water } \\
\text { surface } \\
\text { area(mu) }\end{array}$ & $\begin{array}{l}\text { Water } \\
\text { accumulation }\left(\times 10^{4} \mathrm{~m}^{3}\right)\end{array}$ & $\begin{array}{l}\text { Blocked } \\
\text { river }\end{array}$ \\
\hline Dahaizi & $\begin{array}{l}\text { Jiaochang } \\
\text { Township, } \\
\text { Maoxian } \\
\text { County }\end{array}$ & 3600 & 360 & 81 & 2700 & 7000 & $\begin{array}{l}\text { Minjiang } \\
\text { river }\end{array}$ \\
\hline Xiaohaizi & $\begin{array}{l}\text { Jiaochang } \\
\text { Township, } \\
\text { Maoxian } \\
\text { County }\end{array}$ & 2350 & 290 & 42 & 2025 & 5000 & $\begin{array}{l}\text { Minjiang } \\
\text { river }\end{array}$ \\
\hline Diexihaizi & $\begin{array}{l}\text { Jiaochang } \\
\text { Township, } \\
\text { Maoxian } \\
\text { County }\end{array}$ & 2000 & 300 & 160 & - & 8000 & $\begin{array}{l}\text { Minjiang } \\
\text { river }\end{array}$ \\
\hline Gongpenghaizi & $\begin{array}{l}\text { Songpinggou } \\
\text { Township, } \\
\text { Maoxian } \\
\text { County }\end{array}$ & - & - & - & 403 & 1000 & $\begin{array}{l}\text { Songping } \\
\text { ditch }\end{array}$ \\
\hline Yuerzhaihaizi & $\begin{array}{l}\text { Songpinggou } \\
\text { Township, } \\
\text { Maoxian } \\
\text { County }\end{array}$ & - & - & - & 201 & 100 & $\begin{array}{l}\text { Yuerzhai } \\
\text { ditch }\end{array}$ \\
\hline Bailazhaihaizi & $\begin{array}{l}\text { Songpinggou } \\
\text { Township, } \\
\text { Maoxian } \\
\text { County }\end{array}$ & - & - & - & 101 & 70 & $\begin{array}{l}\text { Songping } \\
\text { ditch }\end{array}$ \\
\hline
\end{tabular}

At present, Diexi Haizi has been developed into a tourist area to bring economic benefits to the local tourism industry. It is necessary to conduct flood inundation studies to calculate whether the remaining two barrier lakes are at risk of collapse and the critical storage capacity of their collapse.

Diexi Dahaizi is located in the upper reaches of Diexi Xiaohaizi. There is a narrow section in the upper reaches. The downstream is also connected to Diexi Xiaohaizi through a narrow section. Normal water level and water level during lowwater periods generally do not break out. This article sets a possible breakdown. The value of has more than doubled the value in the high water area of Diexi Dahaizi. Diexi Dahaizi was formed in 1933, and after successive heavy rains in the middle, there was no outburst, proving its strong stability.

Once the bursting occurring, however, the amount of water will scour out the Minjiang and flow into the Xiaohaizi, which will cause the collapse of this river. This article conducts the analysis of the Dahaizi and Xiaohaizi respectively. The water storage capacity of Xiaohaizi is obviously weaker than that of Dahaizi, therefore, the former could burst while the later not. The human protection in Xiaohaizi is better than Dahaizi because of the favorable terrain and the tourist areas surrounding it. The landform of Xiaohaizi can be fully seen in dry season. Unlike the Dahaizi, the protuberance of the center in Xiaohaizi is a buffer to a part of flood from the upstream Minjiang to Xiaohaizi.

Due to the much smaller water storage capacity, once the Dahaizi bursting, the breaking path of Xiaohaizi will be in accordance with the Figure 4, which is the Minjiang. Minjiang will be scoured If the overloading strikes Xiaohaizi, which will widen the channel and raise the water level. 
Under normal circumstances, it is difficult to reach the capacity of artificially set breaching reservoirs. Since 1933, there have been no breaches in both Dahaizi and Xiaohaizi in Diexi. In recent years, the development of tourist areas has made experts pay attention to the damage to the two barrier lakes. The treatment project also made the two barrier lakes more stable.

\section{Tangjiashan Barrier Lake}

Tangjiashan barrier lake is located in Beichuan County and is the largest barrier lake formed by the Wenchuan earthquake. Therefore, its data records are also very accurate. The relevant parameters of the Tangjiashan dam are as follows:

Table 5

Related parameters of Tangjiashan barrier dam

\begin{tabular}{|ll|}
\hline Name & Tangjiashan barrier dam \\
\hline Dam crest elevation $(\mathrm{m})$ & 741 \\
\hline Dam bottom elevation $(\mathrm{m})$ & 669 \\
\hline Dam crest length $(\mathrm{m})$ & 310 \\
\hline Length along the river(m) & 803 \\
\hline Transverse maximum width $(\mathrm{m})$ & 611 \\
\hline Storage capacity $\left(\mathrm{m}^{3}\right)$ & $2.3 \times 109$ \\
\hline Inflow flow $\left(\mathrm{m}^{3} / \mathrm{s}\right)$ & 80 \\
\hline Peak discharge $\left(\mathrm{m}^{3} / \mathrm{s}\right)$ & 6480 \\
\hline Initial burst width $(\mathrm{m})$ & 58 \\
\hline Initial burst depth $(\mathrm{m})$ & 0.18 \\
\hline Final burst width $(\mathrm{m})$ & 131.2 \\
\hline Final burst depth $(\mathrm{m})$ & 20.8 \\
\hline
\end{tabular}

At present, due to the great changes in geological conditions, we have no way to simulate the collapse of the Tangjiashan barrier lake in 2008 based on DEM data. We can only rely on the data of the Tangjiashan barrier lake extracted this year. The water body data, based on the upstream and downstream positions of the Tangjiashan barrier lake, follows the river course to simulate the dam break of the barrier lake.

After the natural flood discharge under man-made control in 2008, the Tangjiashan barrier lake has been very stable. It has now turned into a bay of "human"-shaped still water and has been listed as a famous national freshwater lake. It has good ecological value. Once the Jiashan barrier lake breaks, it will have the most impact on the "Fujiang", the mother river of Mianyang. It will scour and widen the channel of the Fujiang River, breaking from upstream to downstream.

\section{Hongshi River Barrier Lake}

The Hongshihe barrier lake is the only one among the five barrier lakes in the barrier lake group. It is located between the Libaisi barrier lake and the Donghekou barrier lake. There is also a Shibangou barrier lake upstream. Relatively speaking, once One of the barrier lakes has a breach problem, which will affect all barrier lakes in the Beichuan area. The structure of the barrier dam is filled with block stones, the block stones are interposed with clay, the density is low, and the permeability is high. When analyzing the stability of the Hongshi River barrier dam, the existence of high permeability areas should be considered. This is also the reason why the Hongshi River barrier lake is relatively special. 
Not many people have studied the barrier lake of the Hongshi River. There are currently recorded data on the barrier lake of Hongshi River at that time as shown in the table below. Nowadays, some water conservancy projects to protect the barrier lake have caused changes in the vicinity of the barrier lake. The barrier dam has also been slightly adjusted.

Table 6

Related parameters of Hongshihe Barrage Dam (2008)

\begin{tabular}{|ll|}
\hline Name & Hongshihe Barrage Dam \\
\hline Water level difference $(\mathrm{m})$ & 300 \\
\hline Width of dam bottom $(\mathrm{m})$ & 400 \\
\hline Dam height $(\mathrm{m})$ & 50 \\
\hline Barrier lake length $(\mathrm{m})$ & $200-300$ \\
\hline Rain catchment area $\left(\mathrm{km}^{2}\right)$ & 70 \\
\hline Water storage capacity $\left(\mathrm{m}^{3}\right)$ & $2 \times 10^{8}$ \\
\hline Maximum storage capacity $\left(\mathrm{m}^{3}\right)$ & $4 \times 10^{8}$ \\
\hline Average flood flow $\left(\mathrm{m}^{3} / \mathrm{s}\right)$ & 152 \\
\hline
\end{tabular}

The Hongshihe barrier lake is located in a group of barrier lakes, including the Shibangou barrier lake upstream, the Donghekou barrier lake connected to the Hongshihe barrier lake, and the Libaisi barrier lake downstream of the Hongshihe barrier lake. Among the lakes, the Shibangou barrier lake has the largest water storage capacity in this barrier lake group.

The failure of the barrier lake is very rapid, sometimes it is about 10 minutes, and sometimes it is 20 minutes. It is very necessary to be able to scientifically predict the time of the dam failure of the barrier lake and notify the local residents to evacuate in advance. Once a flood occurs, it will affect the surrounding Guang-Fuzhou Bridge and the G212 Lan-Yu Line. The path of the failure is shown in Figure 5. We can follow the main direction of the failure to plan the evacuation path of the residents. Once the failure occurs, it will affect the downstream of it. Of worship temple barrier lake.

\section{Baige Barrier Lake of Jinsha River}

The dammed lake of the Jinsha River is currently invisible in the image. What we have done so far is to simulate the location of the first landslide to simulate the flooding of the existing Jinsha River. The current Jinsha River is very stable and many have been established. A hydropower station, in order to prevent the collapse of the people's property, was damaged.

There have been two landslides in the Baige dammed lake of the Jinsha River, one in October 2018 and one in November 2018. Both landslides have a dammed body. Some parameters of the dammed body are shown in the table below. 
Table 7

Parameters of Jinsha River Baige Dam

\begin{tabular}{|c|c|c|}
\hline Time & Parameter name & Parameter \\
\hline \multirow[t]{7}{*}{2018.10 .10} & Initial reservoir level(m) & 2932.5 \\
\hline & Initial bottom elevation(m) & 2929 \\
\hline & Inbound flow $\left(\mathrm{m}^{3} / \mathrm{s}\right)$ & 800 \\
\hline & Lowest water level(m) & 2910 \\
\hline & Minimum storage capacity $\left(\mathrm{m}^{3}\right)$ & $9.02 \times 10^{10}$ \\
\hline & Highest water level(m) & 2935 \\
\hline & Maximum storage capacity $\left(\mathrm{m}^{3}\right)$ & $2.784 \times 10^{11}$ \\
\hline \multirow[t]{8}{*}{ 2018.11.03 } & Landslide height(m) & 800 \\
\hline & Landslide top elevation(m) & 3670 \\
\hline & Top elevation(m) & 3718 \\
\hline & Length along the river $(\mathrm{m})$ & 1400 \\
\hline & Length across the valley $(\mathrm{m})$ & 600 \\
\hline & Highest water level(m) & 2956.4 \\
\hline & Original riverbed elevation $(\mathrm{m})$ & 2861 \\
\hline & Actual maximum storage capacity $\left(\mathrm{m}^{3}\right)$ & $5.79 \times 10^{8}$ \\
\hline
\end{tabular}

At present, due to artificial changes in elevation, we cannot use HEC-RAS to simulate the two failures in 2018. We can only simulate the disaster at that time with limited data.

The process of simulating the collapse of the Jinsha River barrier lake is shown in Figure 6. The Jinsha River is the upper reaches of the Yangtze River in China. It has a drop of 3,300 meters and is rich in water resources. It is located at the junction of Tibet and Sichuan. An earthquake caused the Jinsha River to block the river again to form a barrier lake. With the rich water resources of the Jinsha River, it will inevitably be broken within a week. Make timely predictions for the formation of the barrier lake, which is the Baige barrier lake of the Jinsha River. Give us the best warning.

\section{Habitat Quality Analysis Diexihaizi}

\section{Land use transfer matrix}

Diexi Haizi is located in the northeastern part of Maoxian County. During 1990-2005, the land use situation in Maoxian County did not change much. During 2005-2010, the grassland area changed from $1690.5 \mathrm{~km}^{2}$ to $1770.18 \mathrm{~km}^{2}$, with a small increase, and the construction land area changed from $4.19 \mathrm{~km}^{2}$ to $5.64 \mathrm{~km}^{2}$, there is a substantial increase, an increase of $34.6 \%$, the area of woodland has a small decrease in area, the newly added bare land category, the water area changed from $4.1617 \mathrm{~km}^{2}$ to $10.25 \mathrm{~km}^{2}$, a huge increase of $146.39 \%$. 
During this period, Maoxian, as the severely affected area of the Wenchuan earthquake, also had a great impact on land-use changes. The first was the change in the water area. Under the subdivision of the secondary land types, the area increased significantly compared to 2005. The larger ones are the area of river channels and the area of reservoir ponds, which are used to dredge the 34 barrier lakes formed by the Wenchuan earthquake and prevent heavy casualties caused by the collapse of the Diexi barrier lake after the 1933 Diexi earthquake.

Between 2010 and 2015, there was a small decrease in the area of grassland and arable land, and the area of construction land changed from $5.64 \mathrm{~km}^{2}$ to $11.63 \mathrm{~km}^{2}$, an increase of about $106.2 \%$, and the water area and the bare land area did not change much. During this period, the process of urbanization in Maoxian County has been significantly accelerated, and construction land has gradually increased. Most of the increase in construction land is the increase in rural settlements. Tourist areas have also been established near the barrier lake, which has driven local tourism GDP. increase.

Table 8

Land Use Change Matrix in MaoXian County $\left(\mathrm{km}^{2}\right)$

\begin{tabular}{|c|c|c|c|c|c|c|c|c|}
\hline \multirow[t]{2}{*}{ Time } & \multirow[t]{2}{*}{ Land type } & \multicolumn{3}{|c|}{2015} & \multirow[b]{2}{*}{ woodland } & \multirow[b]{2}{*}{$\begin{array}{l}\text { Bare } \\
\text { ground }\end{array}$} & \multirow[b]{2}{*}{ Waters } & \multirow[b]{2}{*}{ total } \\
\hline & & grassland & $\begin{array}{l}\text { arable } \\
\text { land }\end{array}$ & $\begin{array}{l}\text { Construction } \\
\text { land }\end{array}$ & & & & \\
\hline \multirow[t]{7}{*}{1990} & grassland & 1578.1 & 19.2080 & 1.33155 & 110.032 & & 3.1632 & 1711.85 \\
\hline & arable land & 20.031 & 128.5776 & 2.943267 & 14.269 & & 0.6662 & 166.487 \\
\hline & $\begin{array}{l}\text { Construction } \\
\text { land }\end{array}$ & 0.2974 & 0.2126 & 2.8905 & 0.3003 & & 0.0787 & 3.7796 \\
\hline & woodland & 192.581 & 15.703 & 4.5878 & 1786.869 & 3.61729 & 2.6025 & 2005.96 \\
\hline & Bare ground & 0.00093 & & & 0.00079 & & & 0.00172 \\
\hline & Waters & 0.26538 & 0.045 & & 0.067797 & & 3.833 & 4.21147 \\
\hline & total & 1791.29 & 163.746 & 11.7531 & 1911.5397 & 3.61729 & 10.34 & 3892.288 \\
\hline
\end{tabular}

\section{Analysis of Habitat Quality in Maoxian County}

The distribution of habitat quality in Maoxian from 1990 to 2015 has obvious characteristics (Figure 8). Areas above the intermediate level account for the majority. The low-level and lower-level areas are mainly concentrated in the southeast of Maoxian. The areas judged as high-level will be within 25 years. The proportion is decreasing, but the higher-level tone area has increased significantly, and the low-level and lower-level areas have decreased year by year. It can also be seen that the country pays more attention to the protection of environmental quality. During the five years from 2010 to 2015 , the overall habitat quality index did not change much.

Judging from the images of the six phases of 1990-2015, the dammed lake did not have much impact on the surrounding ecology, mainly because the Diexi earthquake occurred in 1933.

After treatment and development, the dammed lake is equivalent to an inland lake In addition to the impact on the surrounding ecology during the development of tourist areas, it can be seen in the 2010 and 2015 images that after the earthquake, the ecology around the barrier lake has deteriorated to a certain extent, which is related to the development of tourist areas. It is also related to changes in geological conditions. Other times, after comparison, the effect on ecology is equivalent to that of inland lakes. 


\section{Tangjiashan Barrier Lake \\ Land use transfer matrix}

The land-use changes in Beichuan County from 1990 to 2015 are shown in Table 9. The grassland area and arable land area have relatively little change. The area of construction land has changed from $4.7 \mathrm{~km}^{2}$ to $12.09 \mathrm{~km}^{2}$, and the growth rate is $157.4 \%$. The rate of increase clearly shows the acceleration of urbanization, the increase in the water area, and also reflects the changes in the ecosystem. In 25 years, the period of greatest change was the period from 2005 to 2010 . This period is a relatively significant period of time. The event was the ' 5.12 ' Wenchuan earthquake, and many dammed lakes were formed at the same time. The largest dammed lake is the Tangjiashan dammed lake in Beichuan.

At present, this dammed lake has stabilized after being discharged by experts and has become an inland freshwater lake with considerable economic benefits.

Table 9

Land Use Change Matrix in Beichuan County $\left(\mathrm{km}^{2}\right)$

\begin{tabular}{|c|c|c|c|c|c|c|c|c|}
\hline \multirow[t]{2}{*}{ Time } & \multirow[t]{2}{*}{ Land type } & \multicolumn{3}{|c|}{2015} & \multirow[b]{2}{*}{ woodland } & \multirow[b]{2}{*}{$\begin{array}{l}\text { Bare } \\
\text { ground }\end{array}$} & \multirow[b]{2}{*}{ Waters } & \multirow[b]{2}{*}{ total } \\
\hline & & grassland & $\begin{array}{l}\text { arable } \\
\text { land }\end{array}$ & $\begin{array}{l}\text { Construction } \\
\text { land }\end{array}$ & & & & \\
\hline \multirow[t]{7}{*}{1990} & grassland & 448.28 & 11.6159 & 0.09351 & 32.3415 & 0.11 & 0.00017 & 492.4337 \\
\hline & arable land & 22.374 & 400.257 & 5.13828 & 82.73533 & 3.62 & 1.6455 & 515.770 \\
\hline & $\begin{array}{l}\text { Construction } \\
\text { land }\end{array}$ & 0.0773 & 0.47655 & 3.689095 & 0.109196 & & 0.3528 & 4.705 \\
\hline & woodland & 29.096 & 105.368 & 3.12086 & 1718.227 & 7.4946 & 0.1205 & 1863.43 \\
\hline & Bare ground & 0.071 & 0.4527 & 0.04703 & 0.11218 & 0.023 & 4.068 & 4.77385 \\
\hline & Waters & 499.89 & 518.17 & 12.0888 & 1833.525 & 11.244 & 6.1872 & 2881.11 \\
\hline & total & 448.28 & 11.6159 & 0.09351 & 32.3415 & 0.106 & 0.0002 & 492.4337 \\
\hline
\end{tabular}

\section{Analysis of Habitat Quality in Beichuan County}

The distribution characteristics of the habitat quality of Beichuan Qiang Autonomous County from 1990 to 2015 are obvious. Areas above the intermediate level account for the majority of the proportions. The low-level and lower-level areas are mainly concentrated in the southeast and central areas of Beichuan County. During the 15 years from 1990 to 2005, the overall habitat quality did not change much. However, in 2010 and 2015, we can clearly see a significant increase in areas with lower habitat quality. The Wenchuan earthquake has caused ecological damage in Beichuan County. A very serious impact.

\section{Hongshi River Barrier Lake}

\section{Land use transfer matrix}

The land-use changes in Qingchuan County from 1990 to 2015 are shown in Table 10. The grassland area decreased slightly, and the cultivated land area changed from $816.987 \mathrm{~km}^{2}$ to $802.045 \mathrm{~km}^{2}$, all with a small decrease. The construction land area changed from $9.04 \mathrm{~km}^{2}$ to $12.62 \mathrm{~km}^{2}$, the growth rate was about $39.6 \%$, the bare land area changed from $38.1 \mathrm{~km}^{2}$ to 
$28.82 \mathrm{~km}^{2}$, the reduction rate was about $24.7 \%$, the water area changed from $11.43 \mathrm{~km}^{2}$ to $32.17 \mathrm{~km}^{2}$, the growth rate was about $182.5 \%$.

Since 1995, Qingchuan County has been in the process of urbanization. Between 1995 and 2000, the area of grassland, woodland, and arable land decreased, and the growth rate of construction land was about $40.5 \%$ increase rapidly.

Table 10 Land Use Transfer Matrix in Qingchuan County $\left(\mathrm{km}^{2}\right)$

\begin{tabular}{|c|c|c|c|c|c|c|c|c|}
\hline \multirow[t]{2}{*}{ Time } & \multirow[t]{2}{*}{ Land type } & \multicolumn{7}{|l|}{2015} \\
\hline & & grassland & $\begin{array}{l}\text { arable } \\
\text { land }\end{array}$ & $\begin{array}{l}\text { Construction } \\
\text { land }\end{array}$ & woodland & $\begin{array}{l}\text { Bare } \\
\text { ground }\end{array}$ & Waters & total \\
\hline \multirow[t]{7}{*}{1990} & grassland & 886.76 & 70.412 & 1.52305 & 53.77 & 0.65 & 2.17685 & 1015.3 \\
\hline & arable land & 57.5955 & 711.67 & 5.6766 & 21.8186 & 0.12 & 20.104967 & 816.9876 \\
\hline & $\begin{array}{l}\text { Construction } \\
\text { land }\end{array}$ & 1.03164 & 1.866 & 4.63396 & 0.03171 & & 1.472674 & 9.036012 \\
\hline & woodland & 35.2214 & 16.41 & 0.72519 & 994.061 & 0.2391 & 0.020596 & 1046.6751 \\
\hline & Bare ground & 0.57276 & & & 9.66535 & 27.816 & & 38.0541 \\
\hline & Waters & 1.27822 & 1.6884 & 0.0599 & 0.0065 & & 8.3922668 & 11.4253 \\
\hline & total & 982.46 & 802.05 & 12.6188 & 1079.35 & 28.8245 & 32.1674 & 2937.47 \\
\hline
\end{tabular}

\section{Analysis of Habitat Changes in Qingchuan County}

The distribution characteristics of the habitat quality of Qingchuan County from 1990 to 2015 are obvious (Figure 10). Areas above the intermediate level account for the majority of Qingchuan County, low-level areas are located in the northeast of Qingchuan County, and lower-level areas are located in the middle and middle of Qingchuan County. In the northeast, as time goes by, lower-level areas have increased, high-level areas have also increased, and intermediate-level areas have decreased significantly. It can be seen that since 2005 , the ecological quality index has dropped significantly.

\section{Baige Barrier Lake of Jinsha River}

\section{Land use transfer matrix}

The Baige barrier lake is special. It is located in Baiyu County in Sichuan Province and half of it is in Jiangda County in the Tibet Autonomous Region.

Jiangda County belongs to Changdu, Tibet Autonomous Region. It is dominated by grassland and forest land. There has been no land type for construction land. Grassland has been decreasing year by year, and cultivated land has been increasing year by year. During 2005-2015, large areas of grassland were under manual intervention. Turned into forest land, part of the reduction of bare land turned into arable land, and part of it widened the water area. The process of urbanization in Baiyu County is not rapid, and various types of land are relatively stable.

Table 11 Land Use Transfer Matrix in Baiyu County $\left(\mathrm{km}^{2}\right)$ 


\begin{tabular}{|c|c|c|c|c|c|c|c|c|}
\hline \multirow[t]{2}{*}{ Time } & \multirow[t]{2}{*}{ Land type } & \multicolumn{7}{|l|}{2015} \\
\hline & & grassland & $\begin{array}{l}\text { arable } \\
\text { land }\end{array}$ & $\begin{array}{l}\text { Construction } \\
\text { land }\end{array}$ & woodland & $\begin{array}{l}\text { Bare } \\
\text { ground }\end{array}$ & Waters & total \\
\hline \multirow[t]{7}{*}{1990} & grassland & 6182.09 & 7.222 & 0.2806387 & 123.23 & 26.7 & 1.4541 & 6340.922 \\
\hline & arable land & 13.2151 & 46.454 & 0.744456 & 0.783 & 0.002 & & 61.19889 \\
\hline & $\begin{array}{l}\text { Construction } \\
\text { land }\end{array}$ & 0.22181 & 0.0354 & 2.344171 & 0.0132 & 0.0011 & & 2.615692 \\
\hline & woodland & 150.373 & 14.672 & 0.104421 & 3275.5 & 2.53399 & 0.31863 & 3443.47 \\
\hline & Bare ground & 53.8521 & 2.2016 & 7.15934 & 3.3018 & 740.113 & 1.21173 & 798.479 \\
\hline & Waters & 0.67672 & 0.0637 & & 0.455 & 0.15771 & 39.451 & 40.80463 \\
\hline & total & 6400.43 & 68.447 & 3.4737577 & 3403.2 & 769.449 & 42.436 & 10687.49 \\
\hline
\end{tabular}

Table 12 Land Use Transfer Matrix in Changdu County $\left(\mathrm{km}^{2}\right)$

\begin{tabular}{|c|c|c|c|c|c|c|c|c|}
\hline \multirow[t]{2}{*}{ Time } & \multirow[t]{2}{*}{ Land type } & \multicolumn{7}{|l|}{2015} \\
\hline & & grassland & $\begin{array}{l}\text { arable } \\
\text { land }\end{array}$ & $\begin{array}{l}\text { Construction } \\
\text { land }\end{array}$ & woodland & $\begin{array}{l}\text { Bare } \\
\text { ground }\end{array}$ & Waters & total \\
\hline \multirow[t]{7}{*}{1990} & grassland & 886.76 & 70.412 & 1.52305 & 53.77 & 0.65 & 2.17685 & 1015.3 \\
\hline & arable land & 57.5955 & 711.67 & 5.6766 & 21.8186 & 0.12 & 20.104967 & 816.9876 \\
\hline & $\begin{array}{l}\text { Construction } \\
\text { land }\end{array}$ & 1.03164 & 1.866 & 4.63396 & 0.03171 & & 1.472674 & 9.036012 \\
\hline & woodland & 35.2214 & 16.41 & 0.72519 & 994.061 & 0.2391 & 0.020596 & 1046.6751 \\
\hline & Bare ground & 0.57276 & & & 9.66535 & 27.816 & & 38.0541 \\
\hline & Waters & 1.27822 & 1.6884 & 0.0599 & 0.0065 & & 8.3922668 & 11.4253 \\
\hline & total & 982.46 & 802.05 & 12.6188 & 1079.35 & 28.8245 & 32.1674 & 2937.47 \\
\hline
\end{tabular}

\section{Habitat quality change of Baige barrier lake}

Baige dammed lake is a dammed lake formed by the 2018 earthquake that blocked the Jinsha River. The Jinsha River is also the boundary between the Tibet Autonomous Region and Sichuan Province. In the first 25 years of the formation of the dammed lake, the regional ecology has been stable. Changes for the better, while the ecology of the region is relatively stable. In 2015 , areas with low habitat quality in Jiangda County accounted for less than $5 \%$. The proportion of high-level areas decreased, and higher-level areas accounted for most of the entire Jiangda County.

\section{Impact of barrier lake on habitat quality}

It can be seen from Table 4 that before 2005, the existence of Diexi Haizi has always had a good impact on the quality of the habitat. When the habitat quality is extracted in the corresponding area, it can also be seen that there will be existing near the barrier lake. Water and soil erosion (Wei et al.2007) has caused a slight decline in the quality of the habitat, but in general, the quality of the habitat is higher than the average habitat in the administrative region, but during the period of 2005-2018, it was affected by the Wenchuan earthquake and its own establishment Due to the tourist area, the habitat quality within $1 \mathrm{~km}$ and 3 $\mathrm{km}$ is lower than the average quality, but within $5 \mathrm{~km}$, the habitat quality is higher than the average. Since 2018, the Maoxian 
government has paid more attention to ecological aspects and has also improved the treatment and improvement of the Diexi Haizi Tourist Area, and the overall quality of the habitat has been improved.

Table13 Habitat Quality Index Table of Diexihaizi Region

\begin{tabular}{|lllll|}
\hline $\begin{array}{l}\text { Habitat } \\
\text { Quality } \\
\text { Year }\end{array}$ & $\begin{array}{l}\text { Average habitat quality in the } \\
\text { administrative area }\end{array}$ & $\begin{array}{l}\text { Average habitat } \\
\text { quality within } \mathbf{~ k m}\end{array}$ & $\begin{array}{l}\text { Average habitat } \\
\text { quality within } \mathbf{~} \mathbf{~ k m}\end{array}$ & $\begin{array}{l}\text { Average habitat } \\
\text { quality within } \mathbf{5} \mathbf{~ k m}\end{array}$ \\
\hline 1990 & 0.761146 & 0.773484 & 0.780399 & 0.784473 \\
\hline 1995 & 0.732541 & 0.759376 & 0.758671 & 0.759321 \\
\hline 2000 & 0.760493 & 0.767039 & 0.773095 & 0.779875 \\
\hline 2005 & 0.760239 & 0.767926 & 0.777523 & 0.783184 \\
\hline 2010 & 0.767832 & 0.755128 & 0.756189 & 0.7715 \\
\hline 2015 & 0.767397 & 0.750328 & 0.756651 & 0.770561 \\
\hline 2018 & 0.767301 & 0.755571 & 0.75638 & 0.771584 \\
\hline
\end{tabular}

After the formation of the Tangjiashan dammed lake and the 2008 Wenchuan earthquake, the average habitat quality of the smallest administrative area tended to be stable at 6 kilometers away from the city. Near the site, the habitat quality within the scope has not been high, especially the closer to the barrier lake, the lower the habitat quality, which is about $63.4 \%$ of the average habitat quality. However, after 2008, the formation of the barrier lake and the artificially planned flood discharge project changed the land type of the barrier lake area, and the quality of the nearby habitat was significantly improved, and the area was stable. However, due to the urbanization process, the surrounding construction Too much land, insufficient vegetation coverage, and ecological damage caused by landslides and mudslides, the area around the barrier lake is still lower than the average habitat quality of the smallest administrative area, which is about $75 \%$ of the average regional habitat quality.

Table14 Habitat Quality Index Table of Tangjiashan barrier lake's Region

\begin{tabular}{|lllll|}
\hline $\begin{array}{l}\text { Habitat } \\
\text { Quality } \\
\text { Year }\end{array}$ & $\begin{array}{l}\text { Average habitat quality in the } \\
\text { administrative area }\end{array}$ & $\begin{array}{l}\text { Average habitat } \\
\text { quality within } \mathbf{~ k m}\end{array}$ & $\begin{array}{l}\text { Average habitat } \\
\text { quality within } \mathbf{3} \mathbf{~ k m}\end{array}$ & $\begin{array}{l}\text { Average habitat } \\
\text { quality within } \mathbf{5} \mathbf{~ k m}\end{array}$ \\
\hline 1990 & 0.763509 & 0.484647 & 0.598242 & 0.666306 \\
\hline 1995 & 0.783317 & 0.475415 & 0.624387 & 0.685129 \\
\hline 2000 & 0.764326 & 0.484861 & 0.603528 & 0.669055 \\
\hline 2005 & 0.765485 & 0.483905 & 0.605249 & 0.67059 \\
\hline 2010 & 0.76825 & 0.575603 & 0.634247 & 0.678516 \\
\hline 2015 & 0.768163 & 0.575319 & 0.634499 & 0.678826 \\
\hline 2018 & 0.76774 & 0.578346 & 0.634132 & 0.678979 \\
\hline
\end{tabular}


The Hongshi River barrier lake is located in Qingchuan County. The average habitat quality of Qingchuan County has been relatively stable, but it is relatively low compared to the average habitat quality of other administrative regions in Sichuan Province. During the period from 1990 to 2005, the habitat quality of the existing Hongshi River dammed lake was far lower than the average habitat quality, and the soil erosion around the area was serious. The farther away from the dammed lake, the higher the habitat quality. However, after the Wenchuan earthquake, after the formation of the dammed lake, the treatment volume of the surrounding habitat has been significantly improved. Within $1 \mathrm{~km}$ of the dammed lake, the quality of the habitat is only lower than $3 \%$ of the average quality.

Table15 Habitat Quality Index Table of Hongshi river barrier lake's Region

\begin{tabular}{|lllll|}
\hline $\begin{array}{l}\text { Habitat } \\
\text { Quality } \\
\text { Year }\end{array}$ & $\begin{array}{l}\text { Average habitat quality in the } \\
\text { administrative area }\end{array}$ & $\begin{array}{l}\text { Average habitat } \\
\text { quality within } \mathbf{k m}\end{array}$ & $\begin{array}{l}\text { Average habitat } \\
\text { quality within } \mathbf{~ k m}\end{array}$ & $\begin{array}{l}\text { Average habitat } \\
\text { quality within } \mathbf{~ k m}\end{array}$ \\
\hline 1990 & 0.641253 & 0.525535 & 0.55862 & \\
\hline 1995 & 0.632644 & 0.50426 & 0.546808 & 0.580107 \\
\hline 2000 & 0.645366 & 0.597843 & 0.595876 & 0.570655 \\
\hline 2005 & 0.645631 & 0.596615 & 0.595476 & 0.606019 \\
\hline 2010 & 0.651756 & 0.633892 & 0.614025 & 0.605629 \\
\hline 2015 & 0.651707 & 0.632957 & 0.613469 & 0.618162 \\
\hline 2018 & 0.651062 & 0.63233 & 0.612869 & 0.617829 \\
\hline
\end{tabular}

The Baige dammed lake of the Jinsha River is a dammed lake produced in the past five years, and it is impossible to analyze the temporal and spatial changes of habitat quality in a long time series. Because the barrier lake is located on the boundary between Sichuan and Tibet, and the habitat quality of two adjacent administrative regions is quite different, it is analyzed separately. Before the barrier lake was formed, due to the large area and sparse population, high vegetation coverage, the slow urbanization process in Tibet, the habitat quality has been relatively good and stable. In contrast, the Sichuan region, due to the rapid urbanization process, has only $83 \%$ of the habitat quality in Tibet. Due to the scarcity of disasters in Tibet, the production of barrier lakes has caused great damage to the habitat. As the scope of impact increases, the regional habitat is still higher than the average habitat. However, the quality of the habitat in Sichuan has been low. After the formation of the dammed lake, the national treatment of the dammed lake has improved the quality of the regional habitat, with an increase rate of about $6 \%$.

Table16 The Habitat Quality Index Table of the Tibet Region of the Baige Barrier Lake of the Jinsha River 


\begin{tabular}{|lllll|}
\hline $\begin{array}{l}\text { Habitat } \\
\text { Quality } \\
\text { Year }\end{array}$ & $\begin{array}{l}\text { Average habitat quality in the } \\
\text { administrative area }\end{array}$ & $\begin{array}{l}\text { Average habitat } \\
\text { quality within } \mathbf{~ k m}\end{array}$ & $\begin{array}{l}\text { Average habitat } \\
\text { quality within } \mathbf{3} \mathbf{~ k m}\end{array}$ & $\begin{array}{l}\text { Average habitat } \\
\text { quality within } \mathbf{5} \text { km }\end{array}$ \\
\hline 1990 & 0.770146 & 0.739012 & 0.814224 & 0.7938 \\
\hline 1995 & 0.776862 & 0.824741 & 0.782854 & 0.807334 \\
\hline 2000 & 0.770267 & 0.722247 & 0.812319 & 0.787187 \\
\hline 2005 & 0.770336 & 0.722246 & 0.812337 & 0.787164 \\
\hline 2010 & 0.759563 & 0.720913 & 0.796773 & 0.824898 \\
\hline 2015 & 0.758102 & 0.721226 & 0.79687 & 0.825197 \\
\hline 2018 & 0.759448 & 0.71252 & 0.796416 & 0.823885 \\
\hline 2020 & 0.660634 & 0.643113 & 0.701646 & 0.70703 \\
\hline
\end{tabular}

Table17 The Habitat Quality Index Table of the Sichaun Region of the Baige Barrier Lake of the Jinsha River

\begin{tabular}{|lllll|}
\hline $\begin{array}{l}\text { Habitat } \\
\text { Quality } \\
\text { Year }\end{array}$ & $\begin{array}{l}\text { Average habitat quality in the } \\
\text { administrative area }\end{array}$ & $\begin{array}{l}\text { Average habitat } \\
\text { quality within } \mathbf{~ k m}\end{array}$ & $\begin{array}{l}\text { Average habitat } \\
\text { quality within } \mathbf{~ k m}\end{array}$ & $\begin{array}{l}\text { Average habitat } \\
\text { quality within } \mathbf{~ k m ~}\end{array}$ \\
\hline 1990 & 0.61751 & 0.693557 & 0.661209 & 0.699403 \\
\hline 1995 & 0.618292 & 0.694049 & 0.661471 & 0.701795 \\
\hline 2000 & 0.616168 & 0.703443 & 0.670174 & 0.701073 \\
\hline 2005 & 0.616163 & 0.703508 & 0.670194 & 0.701064 \\
\hline 2010 & 0.622696 & 0.701423 & 0.672563 & 0.705944 \\
\hline 2015 & 0.622695 & 0.701229 & 0.672774 & 0.706 \\
\hline 2018 & 0.622803 & 0.698214 & 0.668027 & 0.705235 \\
\hline 2020 & 0.661768 & 0.741296 & 0.749642 & 0.767502 \\
\hline
\end{tabular}

\section{Conclusion}

Most barrier lakes are located in mountainous areas. Whether to develop and manage barrier lakes, measures should be taken according to local conditions. High-risk barrier lakes cannot be developed. Demolition of the barrier lake can only construct a project similar to the Baige barrier lake of the Jinsha River. Minimize damage to habitat quality. After simulating flood breaks of all barrier lakes, we learned that the five barrier lakes studied in this paper are currently unlikely to have dam breaks in the barrier lakes. Adjusting the heavy rainfall to more than 1.5 times the existing maximum data will A crash occurred.

After the development of the Diexihaizi, it has tended to be stable. Except for slight soil erosion in the adjacent area, the overall habitat quality is relatively high. They have also barrier lakes formed after the Wenchuan earthquake. Due to the serious disasters, the Tangjiashan barrier lake has a lot of human intervention. Although the Hongshihe barrier lake was also controlled by humans in the later period, there was a natural outburst time in the early stage, so even though it was It has a good impact on the habitat, but the impact is not as strong as the Tangjiashan barrier lake. Moreover, before the formation of 
the two barrier lakes, the areas where they were located belonged to areas with slightly severe water and soil erosion, so after the formation of the barrier lakes, the quality of the habitat was significantly improved. The area where the Baige barrier lake formed on the Jinsha River is located at the junction of Sichuan and Tibet. After the collapse, it will cause serious damage to the Tibet Autonomous Region, but it will have a good impact on the Sichuan region. The basic reason is that earthquake disasters frequently occur in Sichuan, and natural disasters such as landslides and mudslides are severely damaged. After the formation of barrier lakes, they function as lakes in the region, which can conserve water sources, preserve water and soil, and improve the quality of habitats. However, the habitat quality in Tibet has always been high and stable. The stabilizing effect of the barrier lake after the formation of a lake is far less than its destructive effect, and the main area of the barrier lake collapse is located in the Tibet Autonomous Region, so the quality of the habitat is significantly reduced. The lakes in Tibet are mainly glacial lakes, which are partly similar to barrier lakes. Once a disaster occurs, the habitat will be destroyed to a great extent.

Studies have shown that under artificial control, the impact of barrier lakes on the surrounding habitats often outweighs the disadvantages, especially for some areas with serious soil erosion. The barrier lakes have the function of conserving water sources and maintaining water and soil so that the quality of regional habitats has been steadily improved. Tend to be stable, not only in terms of ecology, some non-high-risk barrier lakes can be compared to Diexi Haizi and become tourist areas through engineering construction, providing jobs and economic benefits for the local area. After becoming a tourist area, Diexi Haizi will be in terms of regional habitat. Still stable, with minimal damage to the ecology. High-risk barrier lakes (such as the Jinsha River barrier lake) must be early warning and prevention and control. They have a strong destructive power on the surrounding ecology. Even if it is artificially controlled, the damage to the surrounding ecology is still very large, and it can only be after the collapse., Through the establishment of ecological engineering and policy protection to maintain and improve the regional habitat.

\section{Discussion}

This paper analyzes the events of four dammed lakes, uses the HEC-RAS model to analyze the flood inundation, and uses the InVEST model to analyze the regional temporal and spatial changes. However, there are some shortcomings in the research process. Future research work will mainly start with the application of more reasonable regional habitat analysis methods and the shortest path when floods erupt. (1) The data for 1990-2018 comes from the Resource and Environmental Science Data Center of the Chinese Academy of Sciences, and the classification standards are the same, but the data for 2020 come from the National Natural Resources Administration of China, there are slight differences, which may affect the assessment of habitat quality.

(2) The Jinsha River dammed lake can no longer be seen in the image. What we have done so far is to imitate the location of the first landslide and simulate the formation and failure of the Jinsha River Baige dammed lake. The Jinsha River section It has always been famous for its rich hydraulic resources, accounting for more than $40 \%$ of the Yangtze River's hydraulic resources. The ability to predict the formation of the dammed lake in time is the best reflection on the Baige dammed lake of the Jinsha River. At present, the Jinsha River has stabilized. Unless natural disasters such as landslides and earthquakes occur, it is generally difficult to form a barrier lake. However, the Jinsha River in Tibet has fewer human activities, and disaster prevention and mitigation are relatively more difficult.

\section{Declarations}

Acknowledgements I would like to thank Associate Professor Dai of the Chengdu University of Technology for his guidance and the research support provided by the Chengdu University of Technology.

Funding This study is supported by Research Center for Human Geography of Tibetan Plateau and Its Eastern Slope (No.: RWDL2021-ZD003), and the National Natural Science Foundation of China: Thematic mapping of urban waterlogging disasters based on water conservancy spatiotemporal modeling (approval number: ZRZYBWD202108). And it was approved

Page 19/28 
by the National University Student Innovation and Entrepreneurship Training Program: Remote Sensing and GIS-based Inundation Analysis of Barrier Lake Reservoir Area and Post-disaster Emergency Rescue Planning Research-Taking Maoxian County in the Upper Minjiang River as an example (project number: 201910616001).

\section{Ethical Approval:(Not applicable)}

Consent to Participate: All the co-authors agreed to participate in the research.

Consent to Publish: All the co-authors agreed to publish the manuscript.

Authors Contributions: X. D. initiated and designed the research. F. J., T. X., S. Y. and G. Q. conducted the experiment. Z. X. and Z. H. aided in analyzing the results and guidance. Y. Z., S. Y., Z. Y. and J. X. contributed to the writing and development of the manuscript.All authors discussed the results and contributed to the final manuscript.

Competing Interests: The authors declare that they have no conflict of interest.

Availability of data and materials: All the data and materials related to the manuscript are published with the paper, and available from the corresponding author upon request.(daixiaoai@163.com)

Funding: This research was funded by Research Center for Human Geography of Tibetan Plateau and Its Eastern Slope (No.: RWDL2021-ZD003), and the National College Students Innovation and Entrepreneurship Training Program (No.: 201910616001). National Outstanding Youth Science Fund Project of National Natural Science Foundation of China (ZRZYBWD202108).

\section{References}

1. Chaoying Hu H S, Tianming Zhang. 2017. Environmental impact assessment of barrier lake treatment project based on ecological footprint[J]. People's Yangtze River, 48: 30-32

2. Dai F C, Lee C F, Deng J H, et al. 2004. The 1786 earthquake-triggered landslide dam and subsequent dam-break flood on the Dadu River, southwestern China[J]. Geomorphology, 65.

3. Dongjing Chen Z X 2002. Research on Ecological Security Evaluation of Inland River Basin in Northwest China--A Case Study of Zhangye Region in the Middle Reaches of Heihe River Basin[J]. Arid zone geography: 219-224

4. Dongsheng Chang L Z, Yao Xu, Runqiu Huang. 2009. Risk Assessment of Overtopping Dam Burst in Hongshi River Barrier Lake[J]. Journal of Engineering Geology, 17: 50-55

5. Fan X, Yunus Ali P, Jansen John D, et al. 2019. Comment on 'Gigantic rockslides induced by fluvial incision in the Diexi area along the eastern margin of the Tibetan Plateau' by Zhao et al. (2019) Geomorphology 338, 27-42[J]. Geomorphology.

6. Feng Yu X L, Hong Wang, Hongjing Yu. 2006. Land Use Change and Ecological Security Evaluation in Huangfuchuan Watershed[J]. Acta Geographica Sinica: 645-653.

7. Hafiyyan Q, Adityawan M B, Harlan D, et al. 2021. Comparison of Taylor Galerkin and FTCS models for dam-break simulation[J]. IOP Conference Series: Earth and Environmental Science, 737.

8. Haiwen Li X B 2020. Comprehensive Evaluation of the Restoration Status of Damaged Ecological Space along the Plateau Fragile Area of the Sichuan-Tibet Railway[J]. Journal of Railway Science and Engineering, 17: $2412-2422$.

9. Haohao Li X R, Huabin Yang. 2008. Rescue construction and thinking of Hongshihe dammed lake in Qingchuan County[J]. Water Conservancy and Hydropower Technology (Chinese and English): 50-51+62

10. Hejun Chai, Runqiu Huang, Hanchao Liu I O E G, Chengdu University of Technology 1997. Analysis and Evaluation of the Dangerous Degree of Landslide Blocking the River[J]. Chinese Journal of Geological Hazard and Control: 2-8+16

11. Hong Wang Y L, Lili Song, Yun Chen. 2020. Comparison of characteristics of thunderstorm and gale activity and environmental factors in Sichuan-Tibet area[J]. Journal of Applied Meteorology, 31: 435-446.

Page 20/28 
12. Hongyan $\mathrm{X}, \mathrm{Xu} \mathrm{H}$, Jiang $\mathrm{H}$, et al. 2020. Potential pollen evidence for the $1933 \mathrm{M} 7.5$ Diexi earthquake and implications for post-seismic landscape recovery[J]. Environmental Research Letters, 15.

13. Hui Xu J C, Zhijiu Cui, Pei Guo. 2019. Analysis of Grain Size Characteristics of Sediment in Dammed Lake--Taking Diexi Ancient Dammed Lake in the Upper Minjiang River as an Example[J]. Acta Sedimentologica Sinica, 37: 51-61

14. Jian Yang B P, Min Zhao. 2014. Research on Ecological Restoration Technology in Wenchuan Earthquake-Stricken Area --Taking Tangjiashan Barrier Lake Area as an Example[J]. Sichuan Building Science Research, 40: 164-167.

15. Jian Yang B P 2017. Evaluation of Ecological Quality of Tangjiashan Dammed Lake Region in Beichuan County[J]. People's Yangtze River, 48: 27-32

16. Jianfeng Chen Y W, Yang Li. 2006. Application of HEC-RAS model in flood simulation[J]. Northeast Water Resources and Hydropower: $12-13+42+71$.

17. Jiankang Liu Z C, Tao Yu. 2016. Dam failure risk and its impact of Hongshiyan dammed lake in Ludian, Yunnan[J]. Journal of Mountain Science, 34: 208-215

18. Jianrong Fan B T, Genwei Cheng, Heping Tao, Jianqiang Zhang,Dong Yan, Fenghuan Su. 2008. Information extraction of dammed bodies induced by the May 12 Wenchuan earthquake based on multi-source remote sensing data[J]. Journal of Mountain Science: 257-262.

19. Jinghuan Tian K Z, Meng Chen, Fuxin Chai. 2012. Research on the application of HEC-RAS model in flood risk analysis and assessment[J]. Hydropower Energy Science, 30: 23-25

20. Juan He X W 2015. Dam-break flood analysis based on HEC-RAS and HEC-GeoRAS[J]. Journal of Water Resources and Water Transport Engineering: 112-116

21. Junwei Gan L Y, Jinjun Li. 2017. Research on the Influencing Factors of Sichuan-Tibet Tourism Industry Competitiveness Based on DEMATEL[J]. Arid Land Resources and Environment, 31: 197-202

22. Lansheng Wang L Y, Xiaoqun Wang, Liping Duan 2005. Discovery of the ancient dammed lake in Diexi, Minjiang River[J]. Journal of Chengdu University of Technology (Natural Science Edition): 1-11

23. Ma S, Zhu J, Ya. H. Year. Construction of Risk Assessment System of Dam-break in Barrier Lake Based on Collaborative Workflow: 9.

24. Ming Zeng Y C, Bingyu Zou. 2019. Discussion on the Method of Forecasting the Flood Evolution of Barrier Lake Burst-Taking "11-3" Jinsha River Baige Barrier Lake as an Example[J]. Water Resources and Hydropower Express, 40: 11-14

25. Ouyang C, An H, Zhou S, et al. 2019. Insights from the failure and dynamic characteristics of two sequential landslides at Baige village along the Jinsha River, China Landslides[J]. 16.

26. Peng M, Zhang L M 2012. Analysis of human risks due to dam-break floods-part 1: a new model based on Bayesian networks[J]. Natural Hazards, 64.

27. Qianfeng Li Y L, Gang Liu, Zhiyun Ouyang, Hua Zheng. 2013. The Impact of Land Use Change on Ecosystem Service Function--Taking Miyun Reservoir Watershed as an Example[J]. Acta Ecologica Sinica, 33: 726-736.

28. Qiang Xu G Z, Weile Li, Zhaoyang He, Xiujun Dong, Chen Guo, Wenkai Feng. 2018. Analysis and study of two landslides and dams blocking the river in Baige on the Jinsha River in October and November 2018[J]. Journal of Engineering Geology, 26: 1534-1551

29. Qin Ji J Y, Hongju Chen, Man Li. 2019. Analysis of Economic Differences Along the Sichuan-Tibet Railway from the Perspective of Spatial and Industrial Decomposition[J]. Glacier permafrost: 1-14

30. Qingchun Li Y H, Yubing Shi. 2020. Study on the stability of the residual dam in Tangjiashan dammed lake[J]. Journal of Underground Space and Engineering, 16: 993-998

31. Qiwen Xiang J P, Guangze Zhang, Zhengxuan Xu, Dingkai Zhang, Wenli Tu. 2020. Monitoring and Analysis of Surface Deformation in Zheduo Mountain Area of Sichuan-Tibet Railway Based on SBAS Technology[J]. Surveying Engineering, 29: $48-54+59$ 
32. Shangfu Kuang X W, Jinchi Huang, Yinqi Wei 2008. Analysis and Evaluation of Dam-Break Risk of Barred Lake and Its Influence[J]. China Water Resources: 17-21.

33. Sheng-Hsueh Y, Yii-Wen P, Jia-Jyun D, et al. 2013. A systematic approach for the assessment of flooding hazard and risk associated with a landslide dam[J]. Natural Hazards, 65.

34. Sun L 2021. Research on Fast Perception and Simulation Calculation Method of Landslide Dam in Alpine and Gorge Area: Taking Baige Dammed Lake as an Example[J]. Water Conservancy and Hydropower Technology (Chinese and English), 52: 44-52

35. Tamiru H, O. D M 2021. Application of ANN and HEC-RAS model for flood inundation mapping in lower Baro Akobo River Basin, Ethiopia[J]. Journal of Hydrology: Regional Studies, 36.

36. Tao Pan S W, Erfu Dai, Yujie Liu. 2013. Spatio-temporal changes of water supply services in the ecosystem of the Three Rivers Source Region based on InVEST model[J]. Journal of Applied Ecology, 24: 183-189

37. Vera K, Sergey C, Inna K, et al. 2017. Modeling potential scenarios of the Tangjiashan Lake outburst and risk assessment in the downstream valley[J]. Frontiers of Earth Science, 11.

38. Wang Z 1985. Preliminary Discussion on the Evaluation of Ecological Environment Quality in Minjiang River Basin[J]. Journal of ecology: 29-32

39. Wei Chen Z S, Hui Guo,Hao Wang, Ting Wei, Nan Li, Kaiyi Zhang Shuxiang Yang, Kaijia Dai. 2007. Analysis of Bird Resources and Habitats in Wuhan Urban Lakes and Urban Wetlands in Winter[J]. Forestry Investigation and Planning: 4650

40. Wei G, Gaohong X, Jun S, et al. 2020. Simulation of Flood Process Based on the Model of Improved Barrier Lake's Gradual Dam Break Model \%J Journal of Coastal Research[J]. 104.

41. Wei X, Jiang H, Xu H, et al. 2021. Response of sedimentary and pollen records to the 1933 Diexi earthquake on the eastern Tibetan Plateau[J]. Ecological Indicators, 129.

42. Wei Xu M L, Jie Yang, Chunzhi Li, Xiaojuan Shang. 2011. Risk Analysis of Flood Overflow in Huainan Section of Huaihe River Based on HEC-RAS[J]. Journal of Yangtze River Scientific Research Institute, 28: 13-18

43. Weiwei Zhan R H, Xiangjun Pei, Weile Li. 2017. Research on empirical prediction model of channel type landslide-debris flow movement distance[J]. Journal of Engineering Geology, 25: 154-163

44. Xianju Zheng H L, Wenhai Huang. 2015. Numerical Simulation of Reconstruction of Natural Dams Induced by Heavy Rain --An Example of Tangjiashan Dammed Lake[J]. Business story: 62-63

45. Xiao-Qun W, Xin H, Man S, et al. 2020. Possible relatedness between the outburst of the Diexi ancient dammed lake and ancient Chengdu's cultural change[J]. Journal of Mountain Science, 17: 2497-2511.

46. Xingbo Zhou X D, Yu Yao. 2019. Analysis of the dam-break flood of the Baige dammed lake on the Jinsha River[J]. Hydroelectric Power, 45: 8-12+32

47. Xinhua Zhang R X, Ming Wang, Zhiqiu Yu, Bingdong Li, Bo Wang. 2020. Investigation and analysis of flood disaster caused by dam break of Baige landslide on Jinsha River[J]. Engineering Science and Technology, 52: 89-100

48. Xinxiao Yu B Z, Xizhi Lv, Zhige Yang. 2012. Evaluation of Forest Water Conservation Function of Beijing Mountainous Area Based on InVEST Model[J]. Forestry Science, 48: 1-5

49. Xu J, Guo J, Zhang J, et al. 2021. Route choice model based on cellular automata and cumulative prospect theory: Case analysis of transportation network in Sichuan-Tibet region[J]. Journal of Intelligent \& Fuzzy Systems, 40.

50. Xuan Liang Z Z 2021. Research on the Influence of Numerical Simulation of Tailings Pond Based on FLOW-3D on Downstream[J]. Jiangxi Water Conservancy Science and Technology, 47: 11-20

51. Yu Zheng P Z, Feng Tang, Li Zhao, Xu Zhao. 2018. Research on the Impact of Land Use Change on Habitat Quality in Changli County Based on InVEST Model[J]. China's Agricultural Resources and Regionalization, 39: 121-128

52. Yuanyuan Yang E D, Hua Fu. 2012. Research Framework of Value Evaluation of Ecosystem Service Function Based on InVEST Model[J]. Journal of Capital Normal University (Natural Science Edition), 33: 41-47

Page $22 / 28$ 
53. Yunfei Ma T L, Jinbiao Xiong. 2021. Numerical simulation of dam-break flow based on VOF method and DFBI model[J]. Applied Technology, 48: 23-28

54. Zhe Wu X C, Beibei Liu, Jinfeng Chu, Lixu Peng. 2013. Research progress of InVEST model and its application[J]. Tropical Agriculture Science, 33: 58-62

55. Zhengpeng Li Y H, Yilun Li, Yuehong Ying, Zehua Huangfu. 2021. Numerical simulation of dam-break flood in Qianping Reservoir based on BIM+GIS technology[J]. People's Yellow River, 43: 160-164

56. Zhenming Shi X X, Ming Peng, Minglang Lin. 2015. Analysis of Seepage Stability of Barrier Dam with High Permeability Area--Taking Hongshihe Barrier Dam as an Example[J]. Journal of Hydraulic Engineering, 46: 1162-1171.

57. Zhu J, Qi H, Hu Y, et al. 2012. A DVGE service system for risk assessment of dam-break in barrier lake[J]. International Conference on Automatic Control and Artificial Intelligence (ACAI 2012).

58. Zhu Y, Peng M, Cai S, et al. 2021. Risk-Based Warning Decision Making of Cascade Breaching of the Tangjiashan Landslide Dam and Two Smaller Downstream Landslide Dams[J]. Frontiers in Earth Science.

59. Zuyu Chen G H, Qiang Zhang, Shuaifeng Wu. 2020. Disaster Mitigation Analysis of Cascade Hydropower Stations on the Jinsha River in "11.03" Baige Barrier Lake Emergency Treatment[J]. Hydropower, 46: 59-63

60. Zuyu Chen S C, Lin Wang, Qiming Zhong, Qiang Zhang, Songli Jin. 2020. Inversion analysis of the "11.03" Baige barrier lake burst flood in the upper reaches of the Jinsha River[J]. Science in China: Technological Science, 50: 763-774.

\section{Figures}

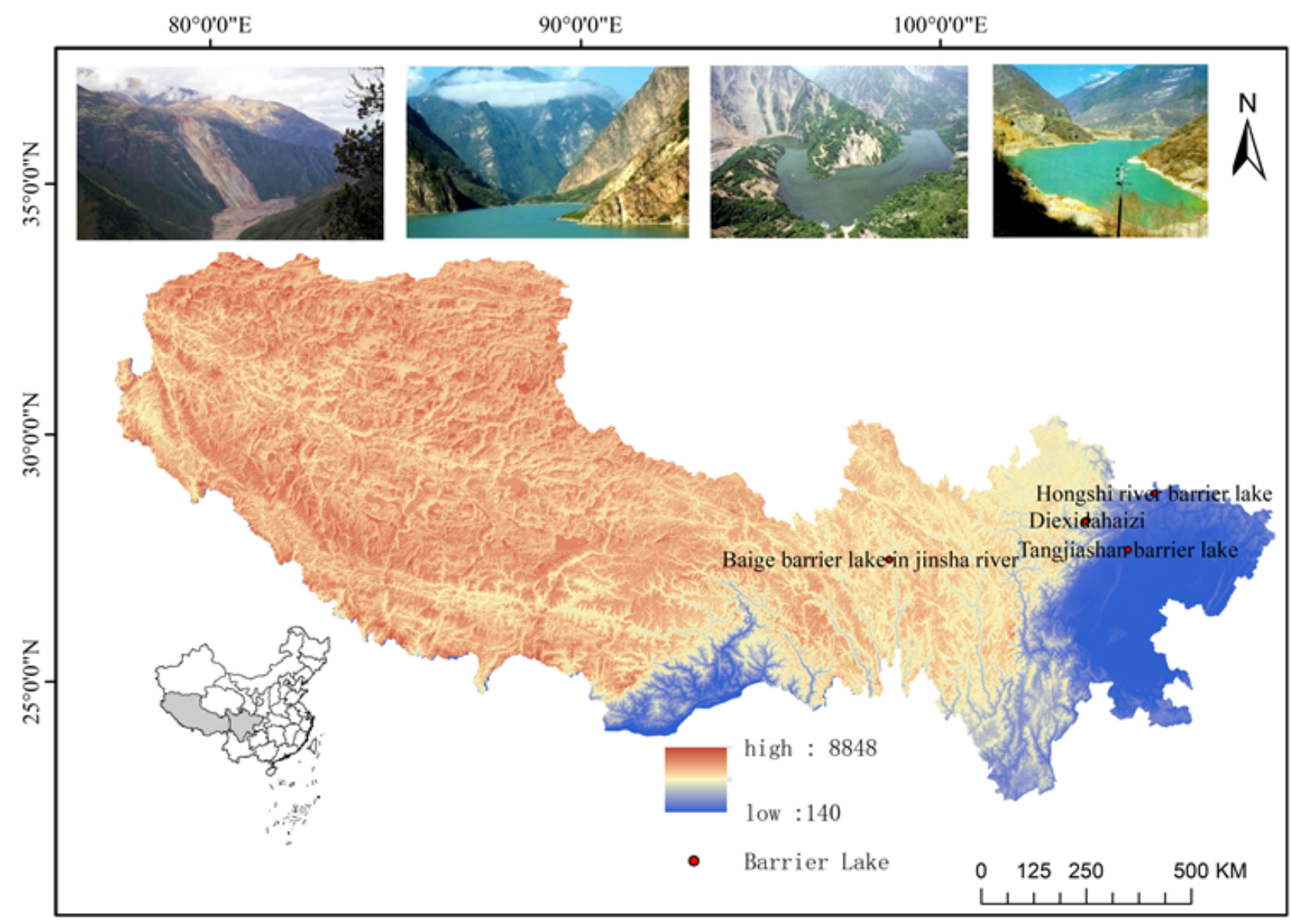

\section{Figure 1}

Location map of barrier lakes, Sichuan-Tibet region, China 


\section{Figure 2}

Framework chart

\section{Figure 3}

The submergence map of Diexi Dahaizi ( (a): Diexi Dahaizi dry season chart; (b): Diexi Dahaizi wet season: artificially set overload; (c): start the dam break for two minutes and thirty seconds; (d): start the dam break for five minutes ; (E): Seven minutes and thirty seconds from the beginning of the dam break (f): Ten minutes after the dam break) )

\section{Figure 4}

Inundation of Diexi Xiaohaizi ( (a): Diexi Xiaohaizi dry season map; (b): Diexi Xiaohaizi wet season: artificial overload; (c): dam break for 4 minutes; (d): dam break for 8 minutes; (e): Twelve minutes after the beginning of the dam break (f): 16 minutes after the dam break) )

\section{Figure 5}

The inundation map of Tangjiashan barrier lake ((A): Tangjiashan barrier lake dry season map; (b): Tangjiashan barrier lake normal conditions (c): Tangjiashan barrier lake wet season: artificially set overload; (d): dam failure for ten minutes (E): 20 minutes of dam failure (f): 30 minutes of dam failure; (g): 40 minutes of dam failure; (h): 50 minutes of dam failure; (i): end of dam failure) 


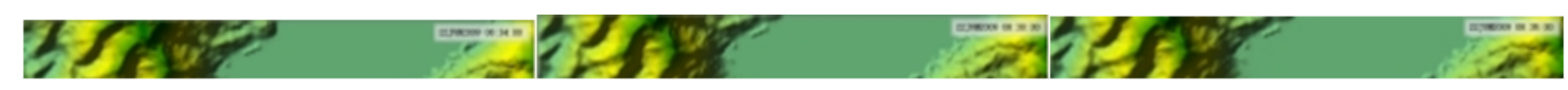

\section{Figure 6}

The inundation map of the Hongshi River dammed lake ((A): the normal state of the Hongshihe dammed lake; (b): the flood period of the Hongshihe dammed lake: artificially set overload; (c): start the dam break for five minutes; (d): start the dam break for ten minutes ; $(E)$ : 15 minutes after the start of the dam break; $(f)$ : the dam break is completed)

展

\section{Figure 7}

The simulated inundation map of the Jinsha River dammed lake ((A): The flood season of the Jinsha River barrier lake: artificially set overload; (b): start the dam break for five minutes; (c): start the dam break for ten minutes; (d): start the dam break for 15 minutes; (e): Twenty minutes after the start of the dam break (f): The dam break is completed) 

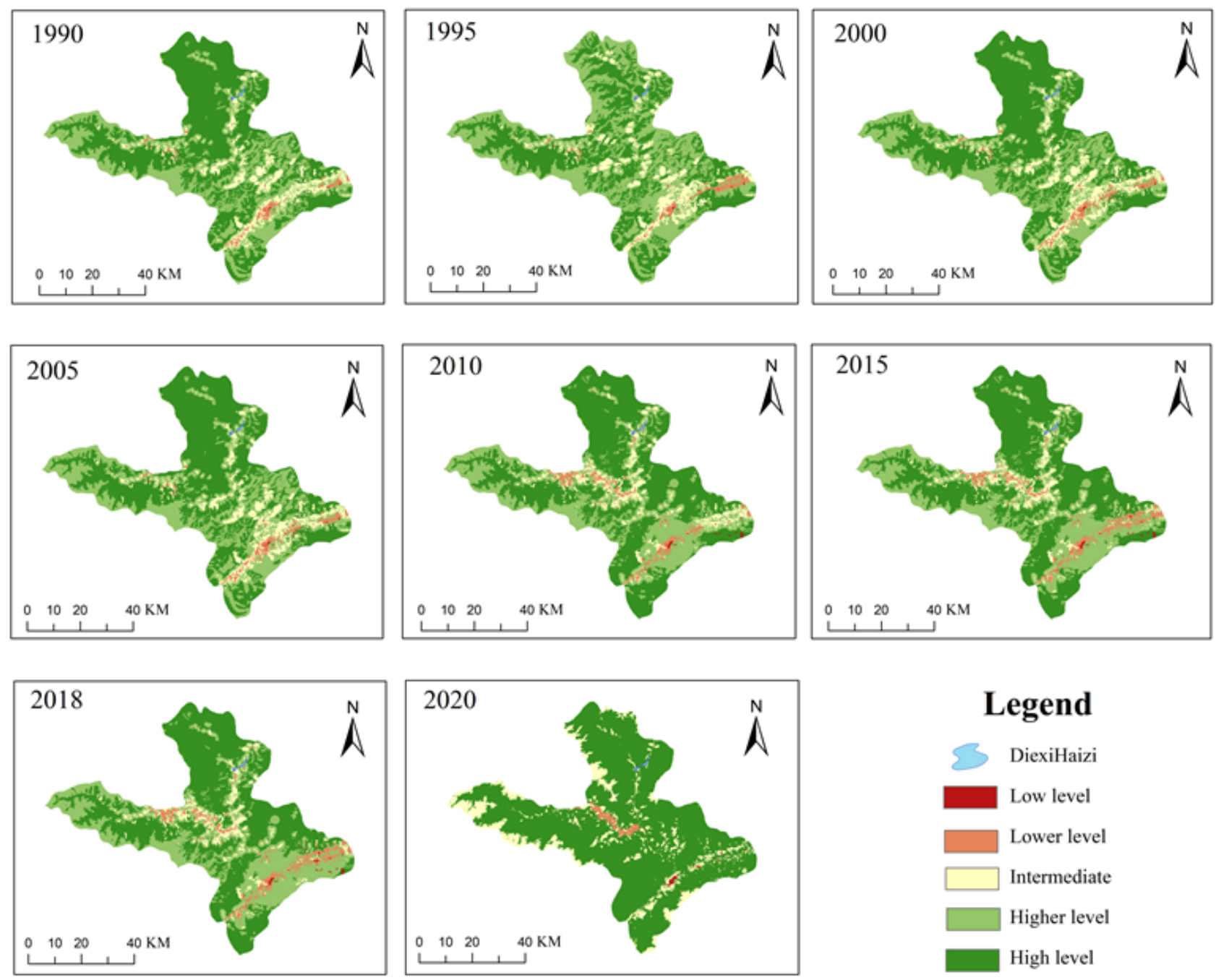

Figure 8

Habitat quality changes in Maoxian County 

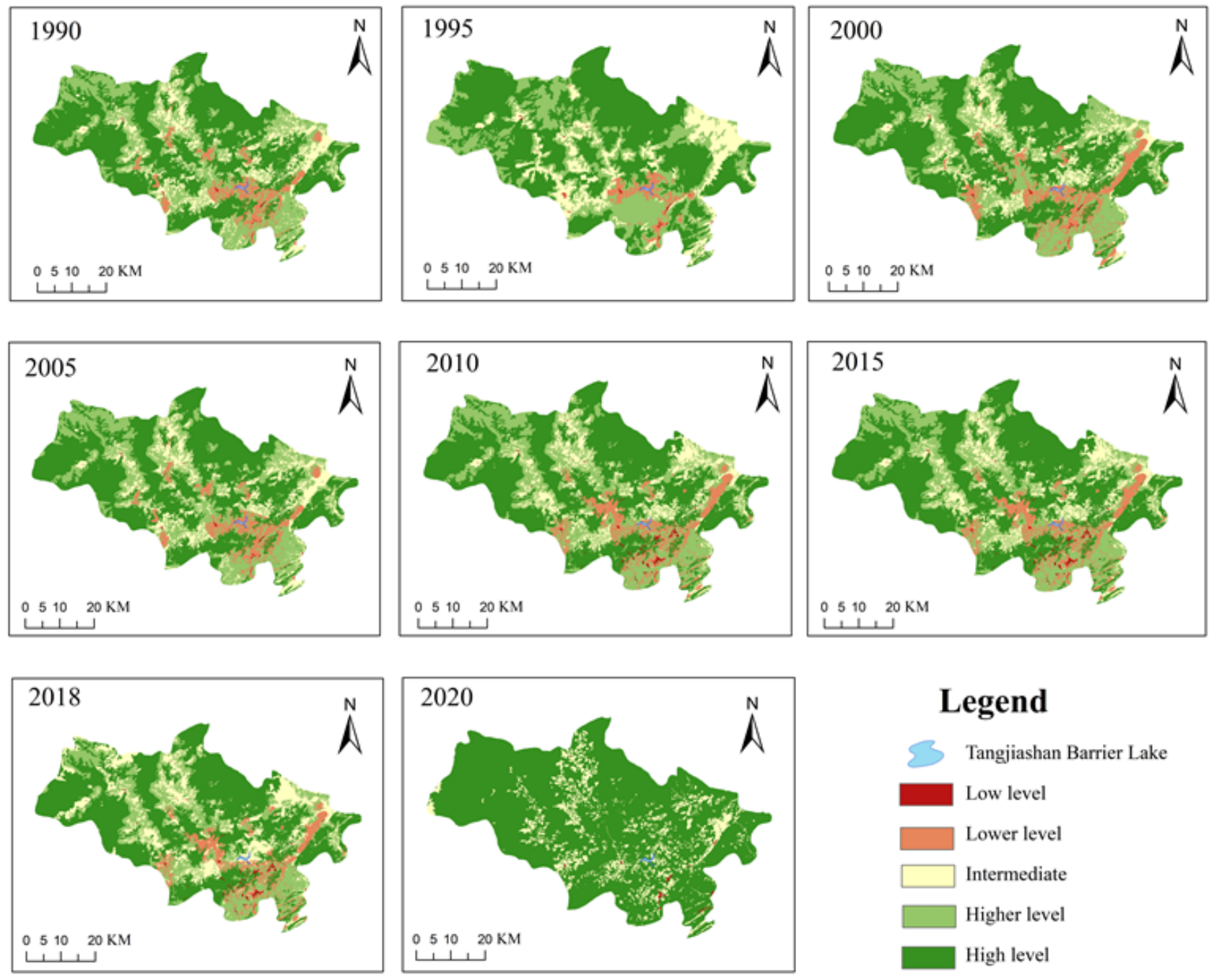

\section{Legend}

$B \quad$ Tangiiashan Barrier Lake
Low level
Lower level
$\square$ Intermediate
$\square$ Higher level
High level

Figure 9

Habitat quality changes in Beichuan County 

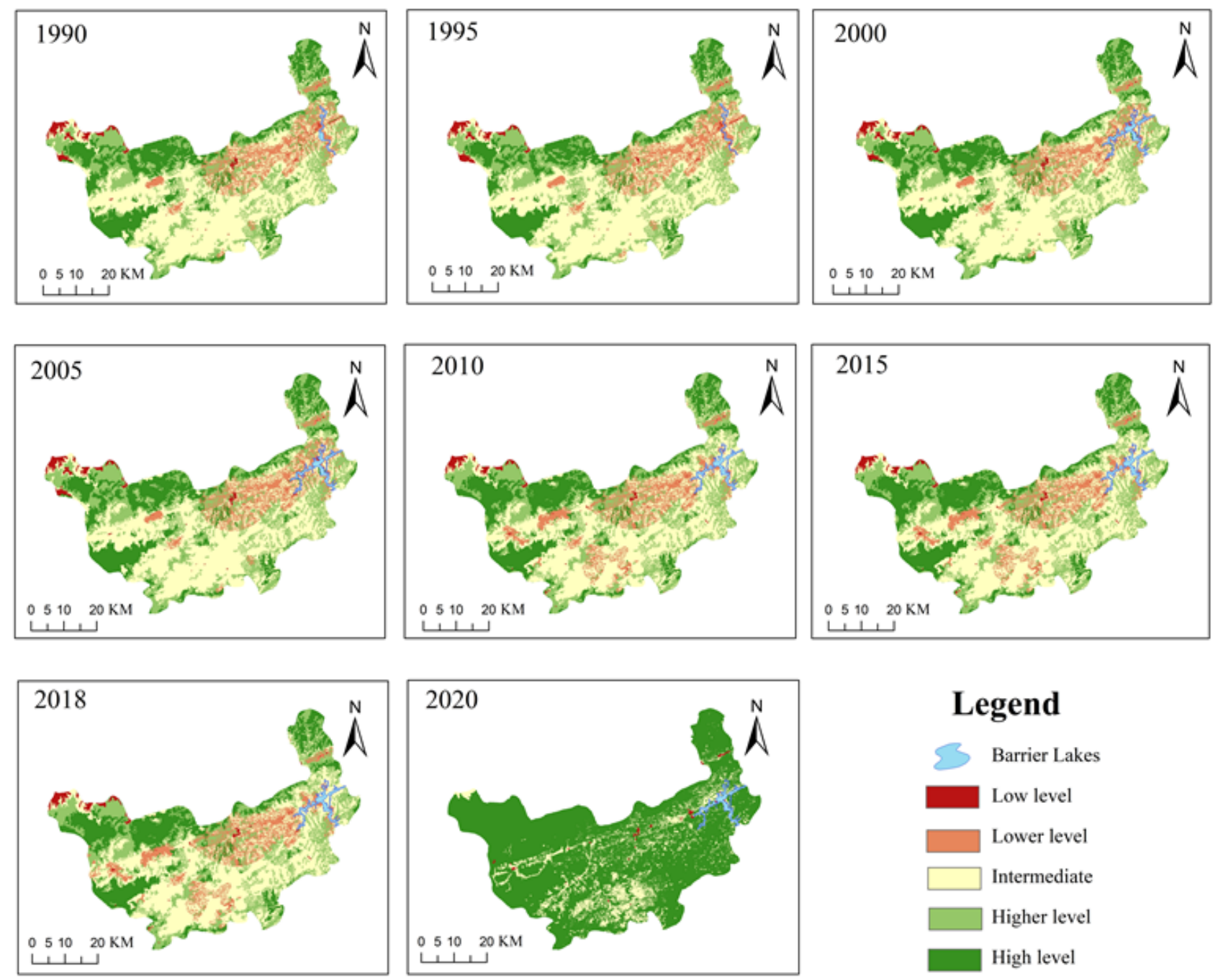

\section{Legend}

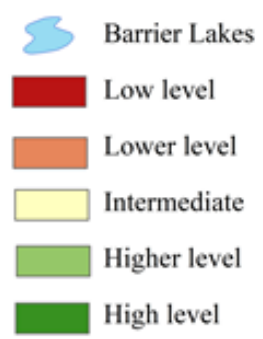

\section{Figure 10}

Habitat quality change map of Qingchuan County 